\title{
Sea scouts plan big splash for oceanography
}

Virginia Gewin, Washington

US researchers are drawing up a wish-list of requirements for an Integrated Ocean Observing System (IOOS), which they hope will radically strengthen the tools available for studying the world's oceans.

A group of 110 academics, government scientists and other researchers met in Warrenton, Virginia, earlier this month to hammer out a consensus on their priorities for the system.

The project has the firm backing of senior members of the Bush administration. And, because their input was requested by a Senate committee, oceanographers are optimistic that funds - perhaps several hundred million dollars in the first few years - will be made available. "The IOOS is an idea whose time has come," says Lou Codispoti, an Arctic Ocean researcher at the University of Maryland's Horn Point Laboratory.

Researchers hope that, if approved, the IOOS will serve as a reliable, comprehensive source of ocean data, similar to the existing National Weather Service. Information would be gathered from buoys, satellites and ships, and would be available to everyone, from military planners to marine biologists. The data obtained would be relevant to issues such as climate change, forecasts of coastal conditions, and the status of fisheries.

The IOOS would have two components, dealing with the open ocean and with US coastal regions, respectively. It would also serve as the US component of the Global Ocean Observing System, an international project that is currently being implemented.

"We are in the midst of a real revolution of how oceanography is conducted," explains Tom Malone, co-chair of the US Global Ocean Observing System Steering Committee. Malone is also joint leader of the IOOS planning efforts.

Advocates of the system say that it will help to transform oceanography, allowing measurements to be repeated easily over time. "The fundamental problem we face right now," says Malone, "is that each piece of the existing system was developed by a particular agency for a particular purpose, so there's an awful lot of redundancy and at the same time we're not getting the information we need."

Participants at the meeting discussed the limitations of current data networks, how new technology might be incorporated, and the logistics of putting new systems in place. A topic of particular interest, say meeting attendees, was the question of how to maintain and disseminate the volume of data that the IOOS is likely to collect. Another priority would be incorporating biological and chemical sensors into existing networks of buoys, built primarily for physical oceanography.
The conclusions of the workshop will be fed into a larger, interagency report to be sent to Congress this summer. This report will include cost estimates for the system, which Malone and others have so far declined to specify.

The US Commission on Ocean Policy, established early last year, is also expected to report in the summer on US national ocean strategy.

The commission's chair is Admiral James Watkins, a former president of the Consortium for Oceanographic Research and Education (CORE), the main lobby group for ocean research. Watkins is publicly committed to the creation of the IOOS. Another advocate is Admiral Conrad Lautenbacher, administrator of the National Oceanic and Atmospheric Administration (NOAA), the US government's main civilian ocean research agency. Lautenbacher says that "there is no achievement too great to imagine from such a system being in place and working".

Academic scientists have one big concern about the system - that its creation will eat into their grant funding from the National Science Foundation and other research agencies. "We're talking about making the case for new money," says Malone.

\section{Jospin reaches out to researchers}

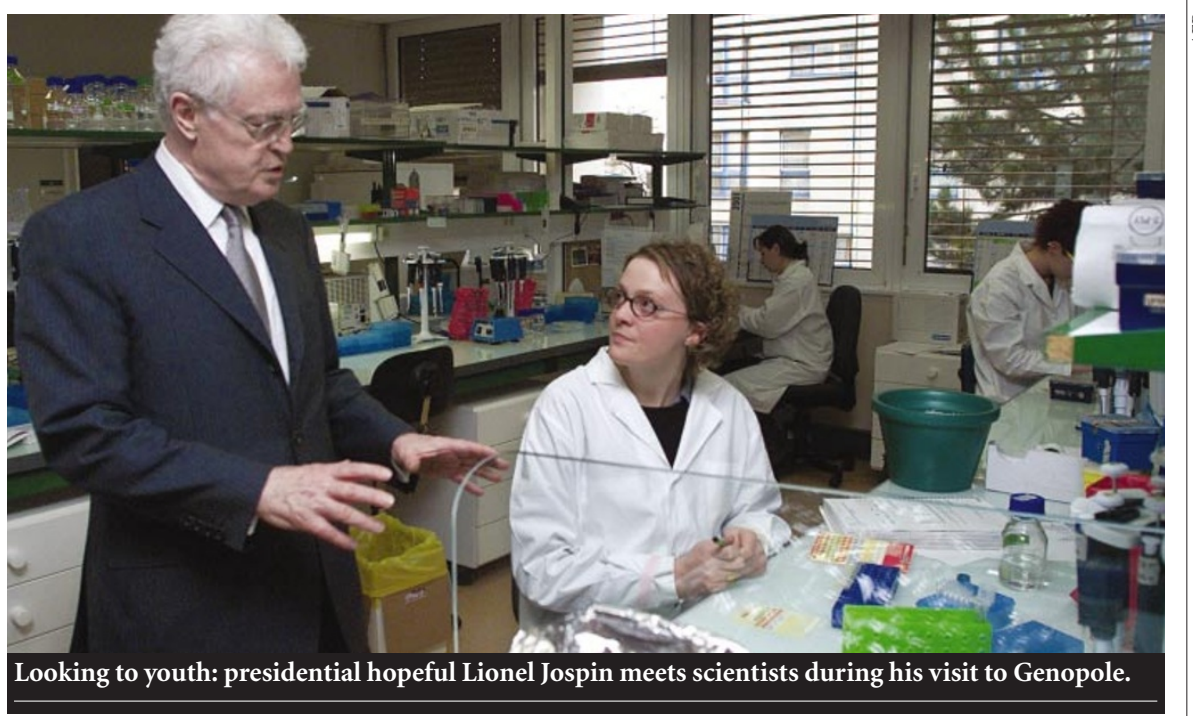

Sally Goodman, Paris

Lionel Jospin, the French socialist prime minister, has pledged a new deal for young researchers if he is elected president.

Speaking at Genopole, the science park in Evry, near Paris, on 13 March, Jospin promised to improve conditions for $\mathrm{PhD}$ students by providing an increased stipend and better career training. He also outlined a proposal to offer researchers permanent positions after two years of postdoctoral work, much earlier than is now the case.

"Increasing the number of posts is not enough to encourage young people to consider research careers if they have to spend years in postdoctoral positions," Jospin said. He also promised to reduce the teaching loads of new university researchers, and to give bigger grants to teams with young leaders.

In addition, he pledged to reorganize the administration of research, creating a new ministry to deal with research, technology and higher education. Jospin had put research under the control of a separate ministry after the sacking in March 2000 of education and research minister Claude Allègre, whose reform attempts sparked a rebellion in the research community (see Nature 404, 421; 2000).

Some researchers have still not forgiven Jospin for standing too long by Allègre, a geochemist at the Paris Geophysical Institute, who is still close to Jospin.

Jospin added that he would try to increase the amount of French gross domestic product that is spent on research and development to $3 \%$, in line with a promise made by European leaders last week.

The two-round presidential elections, on 21 April and 5 May, pitch Jospin against Jacques Chirac, the conservative incumbent. Legislature elections follow in June, and could end a stand-off between Chirac and the legislature's socialist-dominated coalition. Observers say that a president and government of the same party would speed much-needed research reforms. 